\title{
Isolation and quantification of three genes involved in the expression of anthocyanins in rubus glaucus benth by RT-qPCR
}

\begin{abstract}
The violet and purple colored fruits contain phenolic compounds specifically, anthocyanins. These have a high nutritional quality and anthocyanins are believed to have anti-aging, anti-carcinogenic and antioxidant properties in the fruit. Gene expression studies have demonstrated the importance of flavonoids and their biosynthetic pathways, further increasing the interests of research and sources. In the present study, for the isolation and quantification of the $\beta$-Actin, RuANS and RuMYB10 genes involved in the expression of anthocyanins in the cascade of Rubus glaucus Benth, the Real-Time Polymerase Chain Reaction Reverse transcription (RT-qPCR). According to the values obtained with the statistical analyzes DCA and the Turkey test at $95 \%$ confidence, observed a relationship between the genes as no significant differences existed in the expression of the three, generating the following results: Actin presented higher concentration $(273.42 \mathrm{ng} / \mathrm{mL})$, followed by the RuMYB10 gene $(220.33 \mathrm{ng} / \mathrm{mL})$ and finally the Ruans gene $(212.75 \mathrm{ng} / \mathrm{mL})$, concluding that the species studied had similar levels of expression Three genes analyzed.
\end{abstract}

Keywords: anthocyanins, $\beta$-actin gene, RuANS gene, RuMYB10 gene, RT-qPCR, rubus glaucus benth
Volume 5 Issue 3 - 2017

\author{
Viviana Chiluisa-Utreras,' Ivonne Vaca,' Javier \\ Chicaiza, ${ }^{2}$ Sofia Peñaherrera, ${ }^{2}$ Ramiro Daniel \\ Acurio' \\ 'Research Group BIOARN, Salesian Polytechnic University, \\ Quito-Ecuador \\ ${ }^{2}$ Salesian Polytechnic University, Quito-Ecuador
}

Correspondence: Viviana Chiluisa Utreras, MSc, Engineering in Biotechnology, Research Group BIOARN, Salesian Polytechnic University, Av. Isabel La Católica N 23-52 and Madrid, Quito, Ecuador,Tel+593 23962800, Email vchiluisa@ups.edu.ec

Received: September 22, 2017 | Published: December 08, 2017
Abbreviations: RT-qPCR, real-time polymerase chain reaction reverse transcription; ANOVA, analysis of variance; ANS, anthocyanidin synthase

\section{Introduction}

Anthocyanins are secondary metabolites involved mainly in the ripening of fruits. These phenolic compounds are found in leaves, flowers and above all in the fruits of plants. They are incorporated into the human body in daily intake, so the greatest interest lies in the fruits of violet colors. ${ }^{1}$ According to $\mathrm{Wu} \mathrm{X}$ et al., ${ }^{2}$ the estimated daily intake of anthocyanins is $12.5 \mathrm{mg} /$ day/person in the United States, Germany in 2002 , daily intake of $2.7 \mathrm{mg} /$ person, ranging from 0 to $72 \mathrm{mg} /$ person.

At present, interest in the properties of anthocyanins has increased; Miyazawa et al. ${ }^{4}$ state that anthocyanins do not undergo any changes during their passage through the digestive tract into the bloodstream, thus generating their therapeutic effect in reducing coronary disease, improving visual acuity, anticancer effects, antiaging, antitumor and anti-inflammatory, ${ }^{5}$ thanks to its antioxidant activity. ${ }^{6}$

The mora of Castile Rubus glaucus Benth also called mora of Quito, ${ }^{7}$ is a plant of wild origin of the Andes. It is the most produced variety in Ecuador, due to its national and international demand, it is cultivated in diverse countries like: Colombia, Chile, Panama, Guatemala, Mexico and Canada. The fruit of blackberry is consumed both fresh and processed, currently the main markets for this fruit Europe and the United States, have increased the consumption of fruits and vegetables, taking into account the nutritional factor in their diet. $^{8}$
The main objective of the present investigation is to carry out molecular analyzes of gene expression in the biosynthetic pathway of anthocyanins. For this, the RT-qPCR allows us to make qualitative and quantitative measurements of specific genes in a given sample; due to its sensitivity, speed, accuracy and specificity can be used as a more accurate method than conventional techniques. ${ }^{9}$ For the purposes of this analysis, the $\beta$-actin gene has been used as a reference gene, as it is one of the most widely used because of its high concentration. ${ }^{10}$ This allows normalization of a standard curve and generation of reliable data in the analysis. ${ }^{11}$

In this work, we compare the genes most directly associated with anthocyanin biosynthesis in Castile mora, the level of transcription of the gene that specifically controls this compound is anthocyanidin synthase for Rubus (RuANS) and RuMYB10 that encodes a transcription factor and is used for specific regulation in the route. ${ }^{12}$

The knowledge of genes as well as their functioning and expression in the various species, allows the opening to a new era of Transcriptomics and biotechnology in Ecuador, ${ }^{13}$ because it reaches the genomic knowledge not only to understand the but also their applications in the field of health, production, quality and improvement of food.

\section{Materials and methods}

The research was carried out in the Laboratories of Life Sciences at the Salesian Polytechnic University, Laboratory of Molecular Biology, located in Ecuador, Pichincha Province, Canton Quito, El Girón Campus. 


\section{Collection of samples for analysis}

The plant material was collected in the province of Tungurahua, Canton Patate, at an altitude of 2220masl, according to INEN regulations in force in the country. Two field visits were carried out and $1 \mathrm{~kg}$ of fruit were collected aseptically each time, taking into account the organoleptic characteristics. Cryo preserved samples were taken to the Laboratories at the Salesian Polytechnic University for the relevant treatments and analyze.

RNA extraction with pure link® RNA mini kit (ambion, life)

The fruits of Rubus glaucus Benth were macerated in an Eppendorf tube with $1 \mathrm{~mL}$ of the Lysis Buffer solution, homogenized and centrifuged for $2 \mathrm{~min}$ at $12,000 \mathrm{xg}$. In one Eppendorf tube was placed $1 \mathrm{~mL}$ of the supernatant plus $500 \mathrm{~mL}$ of ethanol $(70 \%)$. Then, $700 \mu \mathrm{L}$ were taken, added in a column tube and centrifuged for $15 \mathrm{~s}$ at $12000 \mathrm{xg} .700 \mu \mathrm{L}$ of Wash Buffer I was added and centrifuged for $15 \mathrm{~s}$ at $12000 \mathrm{xg}$, the liquid discarded and placed in a new collection tube, $500 \mu \mathrm{L}$ of Wash Buffer II was added and centrifuged for $15 \mathrm{sec}$ at $12,000 \mathrm{xg}$, discarded the liquid and centrifuged for $2 \mathrm{~min}$ at $12000 \mathrm{x} \mathrm{g}$. Finally, $50 \mu \mathrm{L}$ of free Water of ARNases was added and the centrifuge was taken for $2 \mathrm{~min}$ to $12,000 \mathrm{xg}$.

\section{Transverse transcription with first strand transcriber cDNA synthesis kit (Roche)}

In a microtube, $9 \mu$ l of extracted RNA, $1 \mu$ of vial 5 (Anchoredoligo (dT) Primer), $2 \mu$ l of vial 6 (Random Hexamer Primer), $1 \mu l$ of vial 7 ( $\mathrm{H}_{2} \mathrm{O}$ PCR grade) were placed. $13 \mu$ l of solution were obtained, which were taken to the thermocycler for $10 \mathrm{~min}$ at $65^{\circ} \mathrm{C}$ and cooled to $4^{\circ} \mathrm{C}$. Subsequently, $7 \mu 1$ of the Master Mix was placed in the microtube together with the solution. The thermocycler was taken for $10 \mathrm{~min}$ at $25^{\circ} \mathrm{C}$ for $10 \mathrm{~min}, 55^{\circ} \mathrm{C}$ for $30 \mathrm{~min}, 85^{\circ} \mathrm{C}$ for $5 \mathrm{~min}$ and the cooling at $\infty$ at $4^{\circ} \mathrm{C}$.

\section{Standard curve}

For the elaboration of the standard curve we used Rubus glaucus with the $\beta$-Actin gene, Lin-Wang and others ${ }^{14}$ mention that $\beta$-Actin is selected as a control gene because of its constant level of transcription along leaves and fruits. To obtain the reference values, logarithmic serial solutions of the complementary DNA obtained previously were prepared, the samples were quantified in the Qubit ${ }^{\circledR} 2.0$ Fluorometer, with Qubit ${ }^{\circledR}$ dsDNA HS Assay Kit (Life). ${ }^{13}$

\section{Real-time PCR in light cycler 2.0 (Roche)}

Samples were prepared in each glass capillary with $15 \mu$ of the master mix plus $5 \mu 1$ of the Rubus glaucus cDNA sample. For the negative controls $5 \mu \mathrm{l}$ of water (PCR grade) and the programming of the RT-qPCR: initial denaturation, target temperature $95^{\circ} \mathrm{C}, 1$ cycle; cycled 60 times with three different target temperatures: 95, 60 and $72^{\circ} \mathrm{CC}$. Melting, 1 cycle with target temperatures of 95,65 and $95^{\circ} \mathrm{C}$, cooling, 1 cycle at a temperature of $40^{\circ} \mathrm{C}$.

\section{Results and discussion}

The standard curve points were obtained from the serial concentrations of cDNA on a logarithmic scale in the Qubit ${ }^{\circledR}$ fluorometer for the $\beta$-Actin gene, whereby the quantification of the unknown samples could be performed. The standard curve in acceptable parameters presents an efficiency of 1,922 and an error close to 0 , providing certainty in the tests..$^{13}$

Analysis of variance (ANOVA) with a 95\% confidence level ${ }^{15}$ classifies genes as three homogeneous groups that present with each other, means with statistically non-significant differences, with $\mathrm{F}=2.20$ and $\mathrm{p}=0.1273$. To corroborate the data obtained, a Turkey test was used at $5 \%$, concluding that the 3 genes make up the same group A, so that they are involved in the same way in the biosynthesis of anthocyanins, as can be observed in Figure 1.

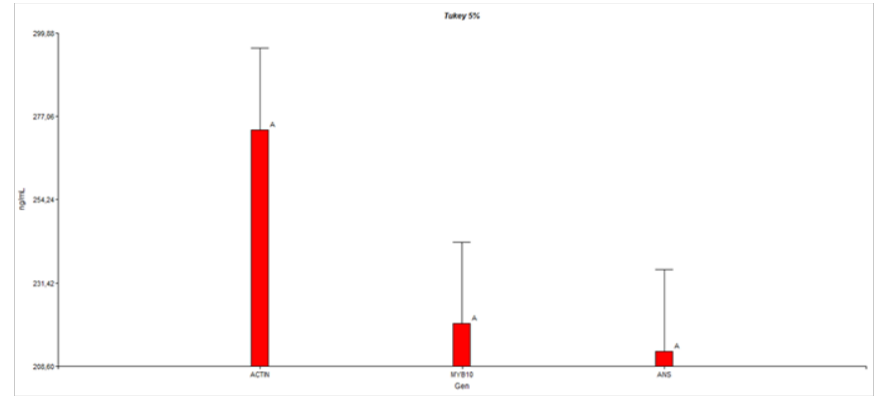

Figure I Turkey's test for the $\beta$-Actin, RuANS and RuMYBIO genes in rubus glaucus benth.

Figure 2 shows a run in the Real-Time PCR with three of the curves obtained for the analysis of the expression of the $\beta$-Actin, RuANS and RuMYB10 genes in Rubus glaucus Benth, thus confirming that all three have similarity, since that the $\mathrm{Cp}$ is very close to the 25 points between the cycles and the fluorescence and therefore the concentration is always inversely proportional to the $\mathrm{Cp}$.

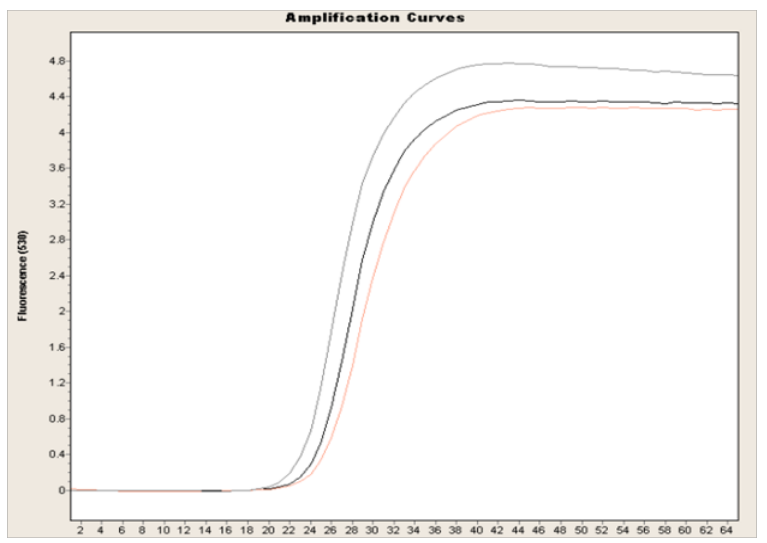

Figure 2 Amplification curves for the $\beta$-actin, RuANS and RuMYBI0 genes: fluorescence vs cycles.

The mean of the concentrations obtained is as follows: for the reference gene $273.42 \mathrm{ng} / \mathrm{mL}$, gene expression is presented with $220.33 \mathrm{ng} / \mathrm{mL}$ for RuMYB10 and 212.75 for the RuANS gene. Almarza $\mathrm{J}^{16}$ mentions that "The metabolic pathway leading to the formation of anthocyanins in different plant species such as Arabidopsis thaliana, Perilla frutescens, Sorghum bicolor, Rubus sp. and others, is regulated at the level of expression of the gene encoding the anthocyanidin synthase (ANS) enzyme "and the MYB gene family is believed to function as mediator of anthocyanin expression. ${ }^{12}$ 
Table 1 shows the distribution of the number of replicates per gene with the averages of their respective concentrations in $\mathrm{ng} / \mathrm{mL}$. The results of this research show that the levels of concentration among the three genes involved in the biosynthesis of anthocyanins in Rubus glaucus Benth are high, with the gene $\beta$-Actin being the highest concentration as a control gene, concluding that the species studied shows a similar level of expression between the three genes analyzed and showing that this species has a high content of anthocyanins.

Table 1 Concentrations (ng/mL) of the $\beta$-Actin, RuANS and RuMYB10 genes in Rubus glaucus

\begin{tabular}{llll}
\hline \multicolumn{4}{l}{ Genes } \\
\hline Repeticiones & $\boldsymbol{\beta}$-Actin & ANS & MYB10 \\
\hline 1 & 240 & 200 & 274 \\
2 & 246 & 124 & 216 \\
3 & 250 & 197 & 152 \\
4 & 416 & 155 & 156 \\
5 & 249 & 295 & 200 \\
6 & 458 & 210 & 115 \\
7 & 225 & 192 & 110 \\
8 & 101 & 250 & 314 \\
9 & 246 & 182 & 208 \\
10 & 258 & 210 & 272 \\
11 & 332 & 220 & 257 \\
12 & 260 & 318 & 370 \\
Promedio(x) & 273.42 & 213 & 220.33
\end{tabular}

Quantitative PCR, due to its sensitivity, speed, accuracy and specificity, can be used to analyze gene expression in a more precise way than conventional techniques, allowing quantitative measurements to be obtained in small quantities of samples that are difficult to collect and generate valuable contribution in the isolation of genes of interest and their application in the industrial field. ${ }^{1}$

\section{Conclusion}

The objectives set out in the present research were fulfilled and the gene expression of $\beta$-actin, RuANS and RuMYB10, involved in the metabolic pathway of anthocyanins in Mora de castilla by RT-qPCR; concluding that the species studied presents a similar level of expression among the three analyzed genes. Currently in Ecuador, we are working on other native species that could even be vulnerable to extinction, the use of molecular biology as a tool for biodiversity management can support the monitoring of natural species and populations, as well as their repontenciación, use and genetic improvement

\section{Acknowledgements}

None.

\section{Conflict of interest}

The author declares no conflict of interest.

\section{References}

1. Chiluisa-Utreras V. Vaccinium floribundum Kunth, reserva de antocianinas en los páramos. Obtenido de PUCE; 2015.

2. Wu X, Beecher G, Holden J, et al. Concentrations of anthocyanins in common foods in the united states and estimation of normal consumption. J Agric Food Chem. 2006;54(11):4069-4075.

3. Xu ZH, Luke R. Howard. Analysis of Antioxidant-Rich Phytochemicals. The Atrium, Southern Gate, Chichester, West Sussex, PO19 8SQ, UK: ohn Wiley \& Sons, Ltd; 2012 p. 1-15.

4. Miyazawa T, Nakagawa K, Kudo M, et al. Direct intestinal absorption of red fruit anthocyanins, cyanidin-3-glucoside and cyanidin-3,5-diglucoside, into rats and humans. J Agric Food Chem. 1999;47(3):1083-1091.

5. Del Carpio C, Serrano C, Giusti M. Caracterizacion de las antocianinas de los frutos de berberis boliviana lechler. revista de la sociedad quimica del peru. Rev Soc Quim Peru. 2009;75(1):76-86.

6. Aguilera M, Reza M, Chew R, et al. Propiedades funcionales de las antocianinas. Revista de Ciencias Biologicas y de la Salud. 2011. p. 16-22.

7. Jardín botánico de Quito. Rubus glaucus. Recuperado el, de Plantas nativas de la hoya de Quito; 2014.

8. Vaca I. Regeneracion de plantas completas de Rubus glaucus BENTH, mediante el uso de reguladores de crecimiento. Recuperado el 5 de, de Escuela Politecnica Del Litoral; 2012.

9. Valasek MA, Repa JJ. The power of real-time PCR. Adv Physiol Educ. 2005;29(3):151-159.

10. Huggett J, Dheda K, Bustin S, et al. Real-time RT-PCR normalisation; strategies and considerations. Genes \& Immunity. 2005;6(4):279-284.

11. Sethi M. $q P C R$ y $R T-q P C R$ con garantia de éxito. Farmespaña Industrial; 2011. p. 63-65.

12. Chen Q, Yu H, Tang H, et al. Identification and expression analysis of genes involved in anthocyanin and proanthocyanidin biosynthesis in the fruit of blackberry. Scientia Horticulturae. 2012;14:61-68.

13. Chiluisa-Utreras V, Vaca I, Chicaiza O, et al. Analysis of the expression of $\beta$-actin, RUANS and RUMYB10 genes involved in the biosynthesis of anthocyanin using RT-qPCR in Rubus niveus in the Rumiñahui Canton. Journal of Berry Research. 2017;7(3):195-201.

14. Lin-Wang K, Bolitho K, Grafton K, et al. An R2R3 MYB transcription factor associated with regulation of the anthocyanin biosynthetic pathway in Rosaceae. BMC Plant Biology. 2010;10:50.

15. Sanchez-Otero J. Introduccion a la estadística en las ciencias biologicas. Quito-Ecuador; 2013.

16. Almarza J. Determinacion de los niveles de expresion del gen (ANS) de la antocianidina sintetasa en cultivares criollo e híbrido de cacao (Theobroma cacao L.). Tesis de Licenciatura en Biología. Merida, Venezuela: Universidad de los Andes; 2002. 